\title{
Sugar Metabolism of Scardovia wiggsiae, a Novel Caries-Associated Bacterium
}

\begin{abstract}
Mai Kameda',2, Yuki Abiko², Jumpei Washio², Anne C. R. Tanner ${ }^{3,4}$, Christine A. Kressirer ${ }^{3,4}$, Itaru Mizoguchi ${ }^{1}$ and Nobuhiro Takahashi ${ }^{2 *}$

${ }^{1}$ Division of Orthodontics and Dentofacial Orthopaedics, Tohoku University Graduate School of Dentistry, Sendai, Japan, ${ }^{2}$ Division of Oral Ecology and Biochemistry, Tohoku University Graduate School of Dentistry, Sendai, Japan, ${ }^{3}$ Forsyth Institute, Cambridge, MA, United States, ${ }^{4}$ Harvard School of Dental Medicine, Boston, MA, United States
\end{abstract}

Scardovia wiggsiae has been detected from caries in children and adolescents and has been suggested to be a caries-associated microorganism. To investigate the cariogenic potential of S. wiggsiae, we examined carbohydrate metabolism and acid productivity, the fluoride sensitivity of carbohydrate metabolism and the mechanism by which fluoride inhibits carbohydrate metabolism, and the acid sensitivity of carbohydrate metabolism in this bacterium. S. wiggsiae metabolized glucose and reduced the environmental pH to 3.5. It mainly produced acetic acid from glucose, together with small amounts of lactic and formic acid. The $50 \%$ inhibitory concentration of fluoride for acid production was $8.0 \mathrm{mM}$ at $\mathrm{pH} 7.0$ and $1.5 \mathrm{mM}$ at $\mathrm{pH} 5.5$, which were much higher than those of representative caries-associated bacteria, such as Streptococcus mutans. Metabolomic profiles showed the accumulation of 3-phosphoglycerate and a marked reduction in the pyruvate concentration in the presence of fluoride, suggesting that fluoride inhibits the latter half of glycolysis, including enolase activity. Enolase activity was inhibited by fluoride in S. wiggsiae, but it was more fluoride-tolerant than the enolase activity of S. mutans. Unlike in S. mutans, lactic acid did not inhibit acid production by S. wiggsiae at acidic $\mathrm{pH}$. These results indicate that $S$. wiggsiae exhibits high acid production and tolerance to fluoride and lactic acid. S. wiggsiae possesses a unique metabolic pathway, the F6PPK shunt, which might allow it to avoid the lactate-formate pathway, including fluoride-sensitive enolase activity, and enable metabolic flow to the fluoridetolerant acetate pathway. The fluoride tolerance of S. wiggsiae's enolase activity also increases the fluoride tolerance of its carbohydrate metabolism. The lactic acid tolerance of S. wiggsiae's acid production might result in S. wiggsiae having high acidogenic and aciduric potential and make it ecologically competitive in acidic environments, such as caries lesions, where lactic acid predominates.

Keywords: Scardovia, acid production, fluoride, Bifid shunt, metabolome, caries, dentistry

\section{INTRODUCTION}

Many children in low income families suffer from early childhood caries (ECC), which remains a public health problem worldwide (Kasebaum et al., 2015). Such lesions progress rapidly and destroy the primary dentition, and moreover, they increase the risk of caries in the permanent teeth. Furthermore successful treatment is difficult and as many as 
$50 \%$ of children relapse after treatment (Tanner et al., 2011; Hajishengallis et al., 2017). The oral biofilm is involved in the formation of ECC and is derived from various factors, such as oral bacteria on the dentin surface, saliva, and dietary carbohydrates (Hajishengallis et al., 2017). Scardovia wiggsiae in addition to Streptococcus mutans and other acid-producing bacteria, have also been associated with white spot initial carious lesions and aggressive caries in adolescents (Tanner et al., 2012; Eriksson et al., 2018).

While $S$. wiggsiae has been detected in ECC without S. mutans, a bacterial complex including $S$. mutans and $S$. wiggsiae characterized adolescents with active caries (Eriksson et al., 2018). S. wiggsiae was isolated from root caries in adults expanding the age range of patients with $S$. wiggsiae associated carious lesions (Mantzourani et al., 2009). Metabolically S. wiggsiae contributes to the acidification of the oral biofilm and is receiving increasing attention as a caries-associated bacterium (Hajishengallis et al., 2017). Although it is recognized that caries-associated bacteria such as S. mutans and lactobacilli can cause caries, it has been reported that other cariesassociated bacteria, including S. wiggsiae, can cause caries even in the absence of the former bacteria, suggesting that it is necessary to clarify the cariogenic potential of the latter bacteria (Chandna et al., 2018).

Scardovia is one of the 7 genera of the Bifidobacteriaceae family. It is a new bacterial genus and was separated from the genus Bifidobacterium in 2002 due to differences in its genome sequence (Jian and Dong, 2002). S. wiggsiae was detected in severe ECC as clone CX010 in 2002 (Becker et al., 2002). Despite limited information about the metabolic pathways of $S$. wiggsiae, the species mainly produces acetate from glucose. This suggests that, like oral Bifidobacterium species, S. wiggsiae possesses a unique metabolic pathway called the fructose-6-phosphate pathway (F6PPK shunt) (Ruas-Madiedo et al., 2005; Sánchez et al., 2005; Manome et al., 2019), which differs from the glycolytic pathway the caries-associated $S$. mutans. However, the biochemical properties of carbohydrate metabolism in $S$. wiggsiae remains incomplete. Thus, the purpose of this study was to examine $S$. wiggsiae for (1) carbohydrate metabolism activity and acid productivity, (2) the fluoride sensitivity of carbohydrate metabolism and the mechanism through which fluoride inhibits carbohydrate metabolism, and (3) the acid sensitivity of carbohydrate metabolism.

\section{MATERIALS AND METHODS}

\section{Bacterial Strains and Growth Conditions}

S. wiggsiae $\mathrm{C} 1 \mathrm{~A} 55^{\mathrm{T}}$ and S. mutans $\mathrm{NCTC} 10449^{\mathrm{T}}$ were used. These bacteria were maintained on CDC anaerobe blood agar (Nippon BD, Tokyo, Japan) at $37^{\circ} \mathrm{C}$ in an anaerobic glove box $\left(\mathrm{N}_{2}, 80 \% ; \mathrm{H}_{2}, 10 \% ; \mathrm{CO}_{2}, 10 \%\right.$; NHC-type; Hirasawa Works, Tokyo, Japan). S. wiggsiae C1A55 was cultured in a brain heart infusion (Becton Dickinson, Franklin Lakes, NJ, United States), supplemented with $0.5 \%$ glucose and $2 \%$ lamb serum, at $37^{\circ} \mathrm{C}$ in the NHC-type box, while $S$. mutans NCTC10449 was cultured in a tryptone-yeast extract-glucose medium, containing $50 \mathrm{mM}$ potassium phosphate buffer ( $\mathrm{PPB}$, $\mathrm{pH} 7.0)$ and $0.5 \%$ glucose. The bacteria were harvested by centrifugation $\left(15,000 \times \mathrm{g}, 10 \mathrm{~min}, 4^{\circ} \mathrm{C}\right)$ during the logarithmic growth phase, using double-sealed centrifuge tubes to maintain anaerobic conditions. Then, the bacterial cells were washed with $2 \mathrm{mM}$ PPB (pH 7.0), containing $150 \mathrm{mM}$ $\mathrm{KCl}$ and $5 \mathrm{mM} \mathrm{MgCl}$, resuspended in the same buffer at an optical density $(660 \mathrm{~nm})$ of 3.5 and stored at $4{ }^{\circ} \mathrm{C}$ prior to use. All of the subsequent procedures, including the washing and preservation of the cells, were carried out in an anaerobic glove box $\left(\mathrm{N}_{2}, 90 \% ; \mathrm{H}_{2}, 10 \%\right.$; $\mathrm{NH}$-type; Hirasawa Works).

\section{Bacteria-Induced pH Reduction and Its Sensitivity to Fluoride}

A pH-stat system (AUTO pH-stat, model AUT-211S; Toa Electronics, Tokyo, Japan) was used to measure the $\mathrm{pH}$ of the reaction mixture, which contained $2.8 \mathrm{~mL}$ of the cell suspension. The $\mathrm{pH}$ of the mixture was adjusted to 7.0 by adding $60 \mathrm{mM} \mathrm{KOH}$, as described previously (Kawashima et al., 2013), before the mixture was pre-incubated at $37^{\circ} \mathrm{C}$ for $3 \mathrm{~min}$. Potassium fluoride (KF) was added to the mixture at a final concentration of $0-25 \mathrm{mM}(1 \mathrm{mM}=19.1 \mathrm{ppmF})$, and then the mixture was further pre-incubated for $4 \mathrm{~min}$. The reduction in $\mathrm{pH}$ was started by adding $10 \mathrm{mM}$ glucose, and the $\mathrm{pH}$ was measured for $50 \mathrm{~min}$.

\section{Bacterial Acid Production and Its Sensitivity to Fluoride}

The reaction mixture containing $2.8 \mathrm{~mL}$ of the cell suspension was set to a pH-stat (AUTO pH-stat; model AUT-211S, Toa Electronics) and was adjusted to 7.0 or 5.5 by adding $0.12 \mathrm{~N}$ $\mathrm{HCl}$, as described previously (Kawashima et al., 2013), before the reaction mixture was pre-incubated at $37^{\circ} \mathrm{C}$ for $3 \mathrm{~min}$. $\mathrm{KF}$ was added to the reaction mixture at a final concentration of 0-20 mM, before the mixture was subjected to further pre-incubation for $4 \mathrm{~min}$. Acid production was started by adding glucose at a final concentration of $10 \mathrm{mM}$. The rate of acid production was monitored for $10 \mathrm{~min}$, based on a titration volume of $60 \mathrm{mM} \mathrm{KOH}$, using the $\mathrm{pH}$-stat system. The $50 \%$ inhibitory concentration $\left(\mathrm{IC}_{50}\right)$ of fluoride was also calculated.

\section{Acidic End-Products}

The concentrations of acidic end-products were analyzed, as described previously (Takahashi et al., 1987; Norimatsu et al., 2015). In the experiment described above, the reaction mixture $(0.45 \mathrm{~mL})$ was sampled before and 10 min after the addition of glucose. The samples were immediately mixed with $0.05 \mathrm{~mL}$ of $6 \mathrm{~N}$ perchloric acid to terminate bacterial metabolism, before being removed from the anaerobic box and filtered through a polypropylene membrane (pore size: $0.20 \mu \mathrm{m}$; Toyo Roshi Ltd., Tokyo, Japan). The filtrates were quantitatively analyzed using high-performance liquid 
chromatography (Shimadzu Prominence LC-20AD, Shimadzu Co., Ltd., Kyoto, Japan).

\section{Metabolome Analysis}

The bacterial suspension was incubated with glucose for $2 \mathrm{~min}$, as described above, in the presence or absence of $5 \mathrm{mM}(\mathrm{pH}$ 7.0) or $2 \mathrm{mM}(\mathrm{pH} 5.5)$ KF. Before and after the incubation procedure, the reaction mixture was sampled and immediately centrifuged at $10,000 \mathrm{rpm}$ for $2 \mathrm{~min}$ in order to separate the cell fraction and supernatant. The metabolites in the cells were extracted from the cell fraction and pre-treated, as reported previously (Takahashi et al., 2010). The extracted metabolites were analyzed using capillary electrophoresis and time-of-flight mass spectrometry (CE-TOFMS; G1600AX and G1969A; Agilent Technologies, Waldbronn, Germany), as described previously (Takahashi et al., 2010). The obtained metabolomic data were analyzed using specific software (MassHunter workstation; Agilent Technologies, CA, United States) and 35 metabolites were identified as described previously. The following metabolites were particularly targeted: glucose 6-phosphate (G6P), fructose 6-phosphate (F6P), 3-phosphoglycerate (3PG), phosphoenolpyruvate (PEP), and pyruvate, which are involved in glycolysis, and erythrose 4-phosphate (E4P), sedoheptulose 7-phosphate (S7P), ribose 5-phosphate (Ribo5P), and ribulose 5-phosphate (Ribu5P), which are involved in the F6PPK shunt.

\section{Inhibition of Enzyme Activity by Fluoride}

$S$. wiggsiae cells were harvested by centrifugation during the logarithmic growth phase, washed twice with $2 \mathrm{mM}$ PPB (pH 7.0), containing $150 \mathrm{mM} \mathrm{KCl}$ and $5 \mathrm{mM} \mathrm{MgCl}_{2}$, and stored at $-80^{\circ} \mathrm{C}$ as a pellet prior to use. The cells were suspended in $2 \mathrm{mM}$ $\mathrm{PPB}$, containing $1 \mathrm{mM}$ dithiothreitol, and then disrupted by sonic oscillation for $10 \mathrm{~min}$ at $4^{\circ} \mathrm{C}(200 \mathrm{~W}, 2 \mathrm{~A}$; Insonator, Kubota, Japan). Cell debris was removed by centrifugation $(10,000 \times \mathrm{g}$, $10 \mathrm{~min}, 4^{\circ} \mathrm{C}$ ), and the enzymatic activity of the resultant cell-free extract (CFE) was assayed. The assay mixture contained $20 \mathrm{mM}$ 2-phosphoglycerate; the CFE; and 0, 2, 5, or $20 \mathrm{mM} \mathrm{KF}$ (pH 7.0) in 2 mM PPB (pH 7.0) (Guha-Chowdhury et al., 1997; Takahashi et al., 1997). Enzymatic activity was measured by monitoring the production of PEP from 2-phosphoglycerate at $240 \mathrm{~nm}$ using a spectrometer (UV-1800; Shimadzu Co., Ltd.).

\section{Effects of Acid on Bacterial Acid Production}

The reaction mixtures containing $2.8 \mathrm{~mL}$ of cell suspension was set to a pH-stat system and adjusted to $\mathrm{pH} 7.0$ or 5.5. Acetate buffer or lactate buffer was added to the reaction mixture at a final concentration of $0-100 \mathrm{mM}$, and the $\mathrm{pH}$ of the reaction mixture was adjusted to 7.0 or 5.5 by adding $\mathrm{HCl}$ or $\mathrm{KOH}$, before the reaction mixture was pre-incubated at $37^{\circ} \mathrm{C}$ for $7 \mathrm{~min}$. Then, $10 \mathrm{mM}$ glucose was added to the mixture, and acid production was monitored as described above.

\section{Statistical Analyses}

The data are expressed as mean and standard deviation values and were analyzed using the paired $t$-test, the paired $t$-test combined with Bonferroni's correction, or Dunn's test. Differences associated with $P<0.05$ were considered to be statistically significant.

\section{RESULTS}

\section{Bacterial Acid Production and Its Tolerance to Fluoride}

Since the acidification by bacterial sugar metabolism on the tooth surface is a causative factor of dental caries, the $\mathrm{pH}$ reduction after the addition of sugar to bacterial suspension was first analyzed in the present study. The $\mathrm{pH}$ remained above $\mathrm{pH} 6.5$ in the absence of glucose, but after the addition of glucose the $\mathrm{pH}$ immediately decreased and fell below the critical $\mathrm{pH}$ of enamel ( $\mathrm{pH} 5.5$ ), reaching $\mathrm{pH} 3.56$ within $2 \mathrm{~h}$ (Figure 1A). The addition of $\mathrm{KF}$ inhibited the reduction in $\mathrm{pH}$ in a concentrationdependent manner.

The acid production produced from glucose by S. wiggisae was monitored based on titration volume of alkali $(\mathrm{KOH})$ solution which is equivalent to the amount of acid production by using a $\mathrm{pH}$-stat (Figure 1B). The acid production rate of $\mathrm{S}$. wiggsiae was $5.9 \pm 4.0 \mu \mathrm{L} / \mathrm{OD}$ at $\mathrm{pH} 5.5$ and $5.6 \pm 0.6 \mu \mathrm{L} / \mathrm{OD}$ at $\mathrm{pH}$ 7.0, i.e., S. wiggsiae exhibited similarly high acid production rates at $\mathrm{pH} 7.0$ and 5.5 (Figure 1B). The addition of KF inhibited acid production in a concentration-dependent manner, but at $\mathrm{pH}$ 7.0 acid production continued even at high KF concentrations $(20 \mathrm{mM})$ (Figure 1B). Based on these findings, the $\mathrm{IC}_{50}$ of fluoride for acid production was calculated, and it was found to be $8.0 \mathrm{mM}$ at $\mathrm{pH} 7.0$ and $1.5 \mathrm{mM}$ at $\mathrm{pH} 5.5$.

\section{Acidic End-Products}

Since the profile of acidic end-products suggests metabolic pathways and inhibition steps by KF, acidic end-products were analyzed. Acetic acid accounted for about $70 \%$ of the acidic end-products produced from glucose, with the remaining acidic end-products being formic acid at $\mathrm{pH} 7.0$ and formic acid and lactic acid at pH 5.5 (Table 1). The addition of KF resulted in a significant decrease in the level of acidic end-products, which was accompanied by an increase in the percentage of acid endproducts accounted for by acetic acid to $85-90 \%$ and reductions in the percentages of acid end-products accounted for by formic and lactic acid.

\section{Effects of Fluoride on the Metabolomic Profile}

To investigate the mechanism of inhibition of carbohydrate metabolism, metabolomic analysis was performed on G6P and F6P in the process of glucose uptake and phosphorylation, E4P, S7P, Ribo5P, Ribu5P, and 3PG in the F6PPK shunt, and PEP and Pyruvate in the latter half of the glycolytic pathway. When fluoride was added during glucose metabolism, 3PG accumulated, and the level of pyruvate decreased (Figure 2). Similar trends were observed at $\mathrm{pH} 7.0$ and $\mathrm{pH} 5.5$, and significant accumulation of $3 \mathrm{PG}$ was seen after the addition of fluoride at $\mathrm{pH}$ 7.0. The accumulation of G6P and E4P was also 
A

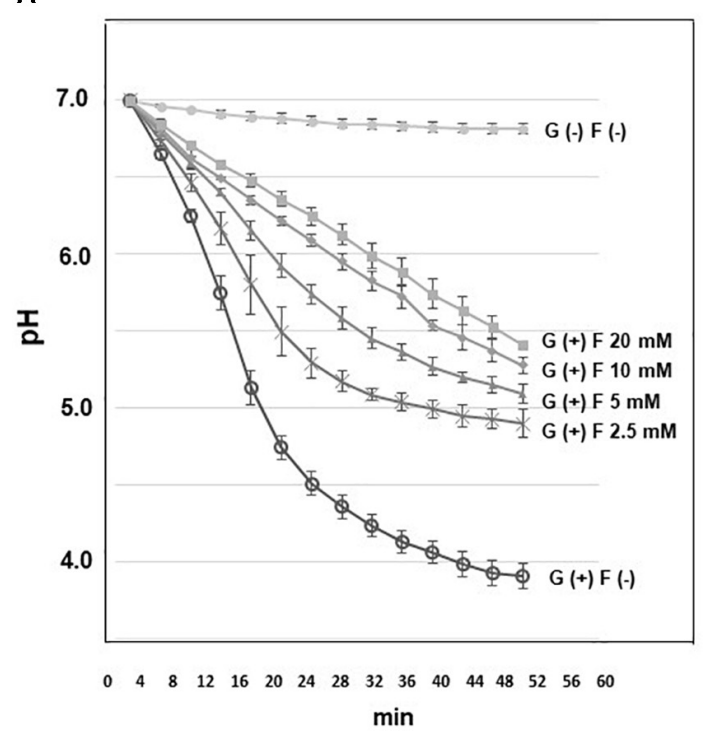

B

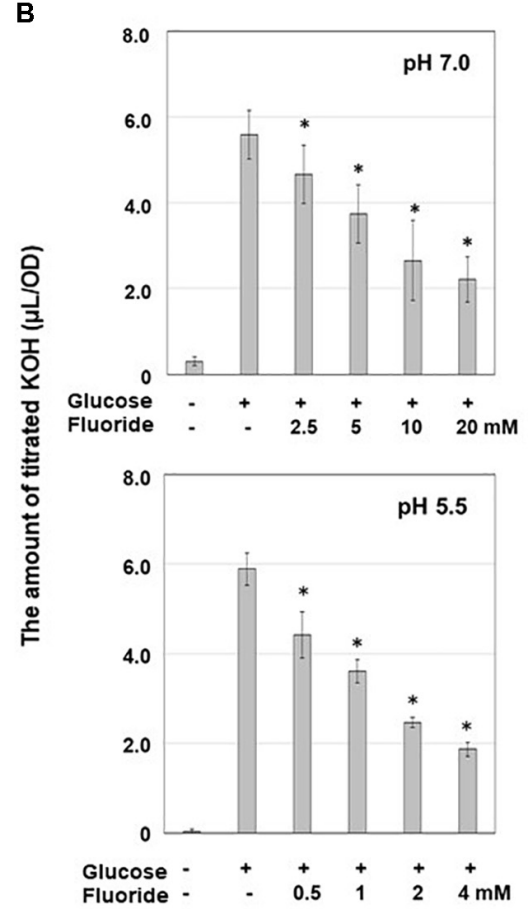

FIGURE 1 | Acid production from glucose by S. wiggsiae and inhibitory effects of fluoride on such acid production. (A) Curves of the reduction in $\mathrm{pH}$ from $\mathrm{pH} 7.0$; (B) the rates of acid production at $\mathrm{pH} 7.0$ and 5.5. The data are shown as the mean and standard deviation of three independent experiments. Fifty percent inhibitory concentrations $\left(\mathrm{IC}_{50}\right)$ were calculated from the fluoride concentration and the rate of acid production. The significance of difference from the control was analyzed using Dunn's test $\left({ }^{*} P<0.05\right)$.

TABLE 1 | Metabolic end-products from glucose at pH 7.0 and 5.5 by S. wiggsiae.

\begin{tabular}{|c|c|c|c|c|}
\hline \multicolumn{5}{|c|}{ Acidic end-products } \\
\hline \multirow[t]{3}{*}{$\mathrm{pH} 7.0$} & $\mathrm{G}(-) \mathrm{F}(-)$ & $27.2 \pm 5.5^{\dagger}(78.4)^{\ddagger}$ & $7.52 \pm 1.8(21.6)$ & ND \\
\hline & $G(+) F(2.5)$ & $80.3 \pm 8.1(74.4)^{\star *}$ & $27.6 \pm 3.7(25.6)$ & ND \\
\hline & $G(+) F(5)$ & $67.1 \pm 8.3(76.0)^{\star \star}$ & $21.1 \pm 2.9(24.0)^{\star \star}$ & ND \\
\hline \multirow[t]{5}{*}{ pH 5.5} & $G(-) F(-)$ & $27.6 \pm 5.8(78.5)$ & $7.56 \pm 2.1(21.5)$ & ND \\
\hline & $G(+) F(-)$ & $104.8 \pm 11.1(71.4)$ & $22.9 \pm 3.1(15.6)$ & $19.0 \pm 1.8(12.9)$ \\
\hline & $G(+) F(0.5)$ & $86.9 \pm 9.2(74.7)^{\star \star}$ & $25.5 \pm 2.6(21.9)^{\star}$ & $3.97 \pm 0.9(3.4)^{*}$ \\
\hline & $G(+) F(1)$ & $76.0 \pm 7.6(77.7)^{\star \star}$ & $21.8 \pm 2.5(22.3)$ & ND \\
\hline & $\mathrm{G}(+) \mathrm{F}(2)$ & $63.0 \pm 7.9(82.3)^{\star \star}$ & $13.6 \pm 2.9(17.7)^{\star \star}$ & ND \\
\hline
\end{tabular}

${ }^{\dagger}$ Data are presented as the mean and standard deviation of three independent experiments ( $\left.\mu M / O D\right)$. ${ }^{\ddagger}$ Relative amount of each acidic end-product compared with the total amount of acidic end-products (\%).

G, $10 \mathrm{mM}$ glucose; F, fluoride (mM).

${ }^{*} P<0.05 ;{ }^{*} P<0.01 ;$ compared with the amount of acidic end-products produced in the presence of glucose.

observed after the addition of fluoride, but these changes were not statistically significant.

\section{Inhibition of Enolase Activity by Fluoride}

Since the inhibition of enolase activity by fluoride was predicted from the metabolomic profile, enolase activity was assayed in cell extracts, and its activity was examined at $\mathrm{pH} 7.0$ after the addition of KF. The addition of fluoride inhibited enolase activity in a concentrationdependent manner, i.e., fluoride inhibited enolase activity by $<10 \%$ at $2 \mathrm{mM}$ (Table 2) and by $50 \%\left(\mathrm{IC}_{50}\right)$ at $4.6 \mathrm{mM}$ (data not shown). 

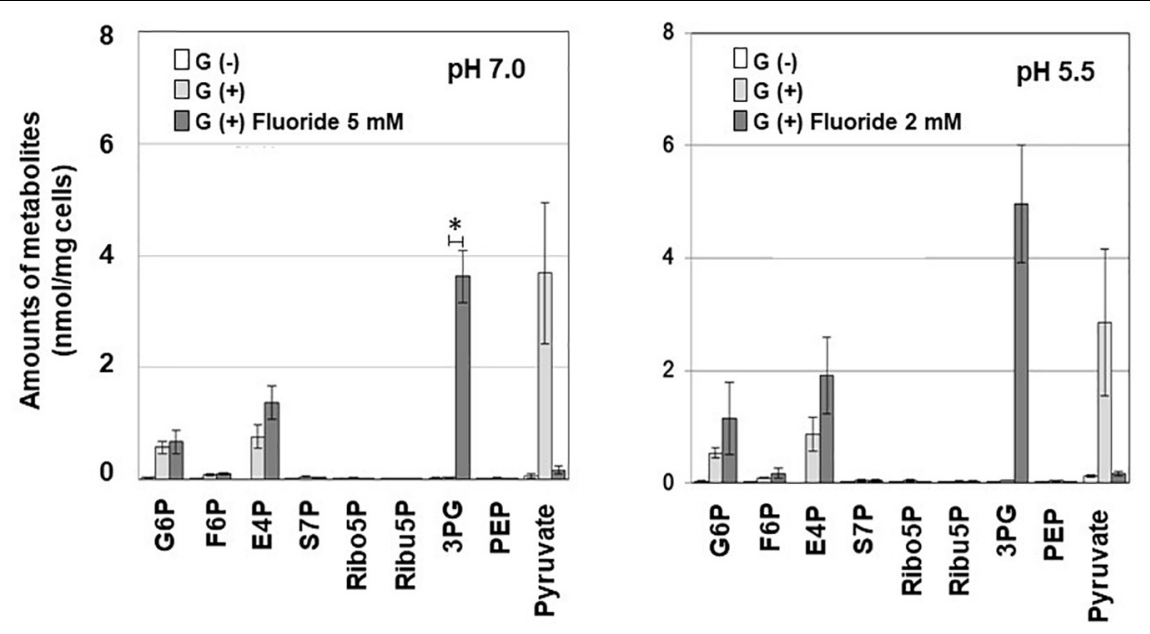

FIGURE 2 | Effects of fluoride on the metabolomic profile of S. wiggsiae at pH 7.0 and 5.5. Data are shown as the mean and standard deviation of three independent experiments. The significance of differences between the with and without fluoride conditions were analyzed using the paired $t$-test. The level of significance was set at 0.00556 , based on Bonferroni's correction ( ${ }^{\star} P<0.0056$ ).

TABLE 2 | Inhibition of enolase activity by fluoride.

\begin{tabular}{|c|c|c|c|}
\hline \multirow{2}{*}{$\begin{array}{l}\text { Fluoride concentration } \\
\text { (mM) }\end{array}$} & \multicolumn{3}{|c|}{ Inhibition of enolase activity by fluoride (\%) } \\
\hline & S. wiggsiae & B. dentium & B. dentium \\
\hline 0.02 & $\mathrm{nt}$ & $10.4 \pm 2.5$ & $7.6 \pm 3.3$ \\
\hline 0.2 & nt & $49.4 \pm 4.7$ & $7.6 \pm 3.3$ \\
\hline 2 & $8.53 \pm 4.7$ & $96.2 \pm 1.0$ & $94.9 \pm 2.5$ \\
\hline 5 & $55.5 \pm 4.8$ & $\mathrm{nt}$ & nt \\
\hline 20 & $92.5 \pm 1.8$ & $\mathrm{nt}$ & $\mathrm{nt}$ \\
\hline
\end{tabular}

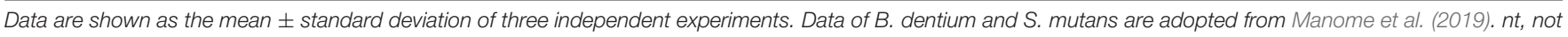
tested.

\section{The Effect of Acid on Bacterial Acid Production}

At $\mathrm{pH} 7.0$, neither lactic acid nor acetic acid affected carbohydrate metabolism in S. mutans or S. wiggsiae (Figure 3). At pH 5.5, lactic acid inhibited the acid production of $S$. mutans, whereas acetic acid did not affect acid production in either bacterium.

\section{DISCUSSION}

S. wiggsiae produced acid from glucose and reduced the environmental $\mathrm{pH}$ to 3.5 (Figure 1A), demonstrating that this bacterium exhibits high acid productivity and tolerance to acidic conditions. In addition, the rate of acid production was similar at both $\mathrm{pH} 7.0$ and 5.5 (Figure 1B), indicating that the acid production pathways of $S$. wiggsiae are acid-tolerant. This result agrees with the findings of a previous study, which demonstrated that $S$. wiggsiae could grow and produce acid at a low $\mathrm{pH}$ (Tanner et al., 2018). In addition, S. wiggsiae is primarily an anaerobic bacterium whereas $S$. mutans is a facultative anaerobic bacterium, suggesting that $S$. wiggsiae can survive and continue to produce acid under more mature biofilm with low oxygen concentration. These facts suggest that acid product from S. wiggsiae could induce hydroxyapatite demineralization and facilitate caries progression by lowering the $\mathrm{pH}$ of the oral biofilm. A previous study found that mutans streptococci, which have high cariogenic potential, can reduce the environmental $\mathrm{pH}$ to 3.5 (Aizawa et al., 2009), which suggests that the acid productivity and acid tolerance of $S$. wiggsiae are equivalent to those of $S$. mutans. This might be one of the reasons why $S$. wiggsiae is frequently detected in caries lesions (Tanner et al., 2012; Colombo et al., 2017; Chandna et al., 2018).

As was reported for Bifidobacterium dentium and Bifidobacterium longum, acetic acid was the main acidic end-product by $S$. wiggsiae (Table 1), whereas many cariesassociated bacteria, such as mutans streptococci, predominantly produce lactic acid (Manome et al., 2019). This suggests that S. wiggsiae, like Bifidobacterium species, metabolizes sugars via the F6PPK shunt and produces acetic acid as an acidic end-product (Figure 4). In the whole genome sequence of S. wiggisiae F0424, the gene sequences of two key enzymes of the F6PPK shunt, transaldolase and transketolase (Figure 4), have been assigned ${ }^{1}$, supporting the involvement of the F6PPK shunt in the sugar metabolism of S. wiggsiae. The F6PPK shunt

\footnotetext{
${ }^{1}$ https://www.ncbi.nlm.nih.gov/Taxonomy/Browser/wwwtax.cgi?id=857290
} 


\section{S. wiggsiae}

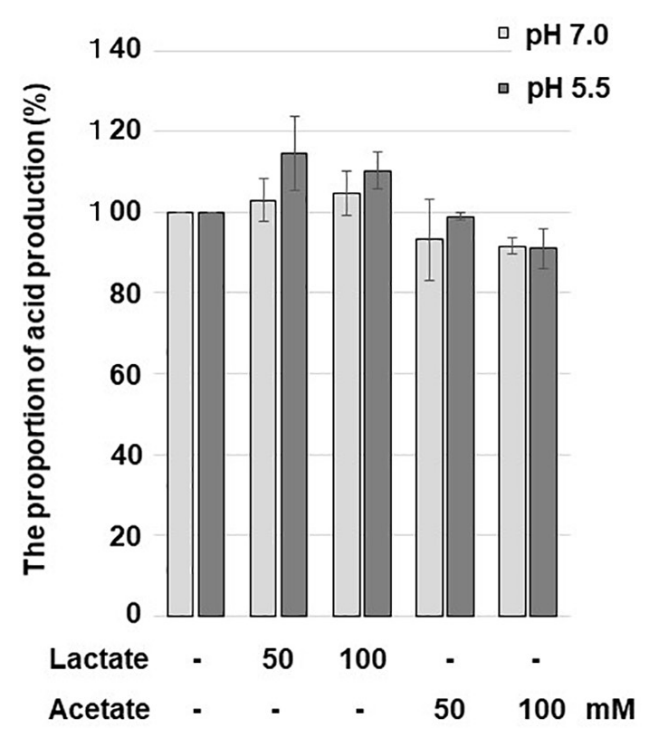

S. mutans

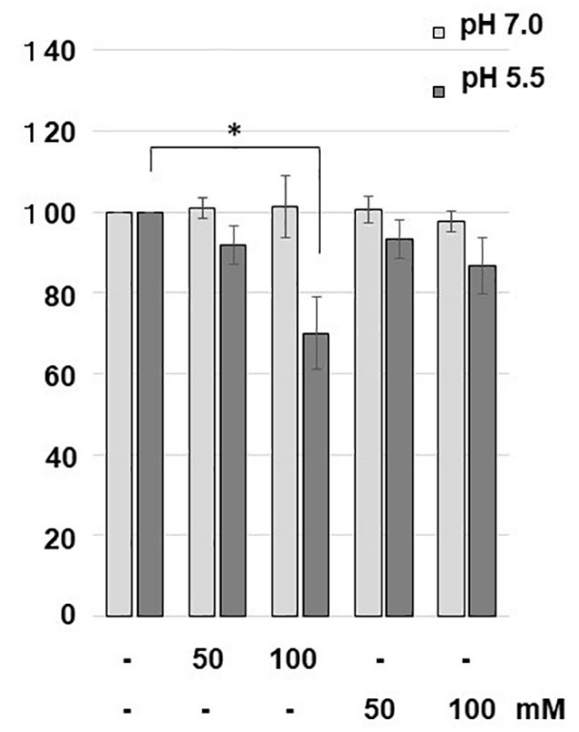

FIGURE 3 | Effects of acetic and lactic acids on acid production from glucose by S. wiggsiae. The significance of differences from the control was analyzed using Dunn's test ( $\left.{ }^{\star} P<0.05\right)$.

is a metabolic pathway, in which the F6P produced by the phosphorylation of glucose is continuously degraded by the enzymatic activities of transaldolase and transketolase, before it finally enters the latter half of glycolysis via G3P and produces lactic and formic acids (the lactate-formate pathway), or is used to convert acetyl phosphate to acetic acid (the acetate pathway) (Figure 4). In addition to acetic acid, S. wiggsiae also produced small amounts of formic and lactic acids (Table 1), indicating that it utilizes both of the abovementioned pathways. Only acetic and formic acids were produced at $\mathrm{pH}$ 7.0, while lactic acid was also produced at $\mathrm{pH} 5.5$ (Table 1), suggesting that a metabolic shift between lactic and formic acids occurred in the lactate-formate pathway. Lactate dehydrogenase, responsible for lactic acid production, was reported to function under acidic conditions in oral streptococci, whereas pyruvate formate lyase responsible for formic acid production functions at neutral $\mathrm{pH}$, because of differences between their optimum $\mathrm{pH}$ (Iwami et al., 1992). This could also be the case in S. wiggsiae. In addition, a previous study found that compared with lactic acid a greater proportion of acetic acid is non-ionized in low $\mathrm{pH}$ environments, and hence, acetic acid is more likely to penetrate into enamel and decalcify it from inside than lactic acid (Hoppenbrouwers and Driessens, 1988), suggesting that acetic acid-producing bacteria, such as $S$. wiggsiae, induce caries formation and encourage caries to progress via different mechanisms to lactic acid-producing bacteria, such as $S$. mutans.

The present study revealed that fluoride inhibits acid production by $S$. wiggsiae more efficiently at acidic $\mathrm{pH}$ than at neutral $\mathrm{pH}$ (Figure 1). Fluoride is present as fluoride ions in the oral cavity, but enters bacterial cells as hydrogen fluoride (Jenkins, 1999). The hydrogen fluoride in bacterial cells changes back to the ionized form of fluoride, which inhibits enolase, an enzyme involved in glycolysis, and hence, carbohydrate metabolism in Streptococcus, Actinomyces, and Bifidobacterium (Hamilton, 1990; Marquis, 1990; Tatevossian, 1990; Jenkins, 1999; Vogel et al., 2002). Since the $\mathrm{pKa}$ of hydrogen fluoride is 3.17 , it is considered that the inhibitory effects of fluoride are increased in acidic environments (Sutton et al., 1987; Jenkins, 1999) because the lower the $\mathrm{pH}$ of the surrounding environment the more fluorine ions are converted into hydrogen fluoride, and thus, the easier it is for fluoride to enter bacterial cells. It seems likely that a similar phenomenon occurs in S. wiggsiae. The current study demonstrated that the $\mathrm{IC}_{50}$ of fluoride for acid production in S. wiggsiae was $8.0 \mathrm{mM}$ at $\mathrm{pH} 7.0$ and $1.5 \mathrm{mM}$ at $\mathrm{pH} 5.5$, which are similar to the values obtained for the Bifidobacterium strains examined (16.4 $\mathrm{mM}$ at $\mathrm{pH} 7.0$ and $1.5 \mathrm{mM}$ at $\mathrm{pH} 5.5)$ and much higher than those for S. mutans $(2.7 \mathrm{mM}$ at $\mathrm{pH} 7.0$ and $0.3 \mathrm{mM}$ at $\mathrm{pH}$ 5.5) (Manome et al., 2019), suggesting that carbohydrate metabolism pathways in S. wiggsiae are highly tolerant to fluoride.

Fluoride also increased the proportion of acetic acid and decreased the proportions of formic and lactic acids among the acidic end-products (Table 1), indicating that the lactateformate pathway is more sensitive to fluoride than the acetate pathway. These results are consistent with the metabolomic profile (Figure 2), which showed that fluoride had little effect on the pathway from glucose uptake through G6P to $\mathrm{F} 6 \mathrm{P}$ or on the levels of metabolic intermediates in the F6PPK shunt, whereas it did affect the levels of metabolic intermediates in the lactate-formate pathway (Figure 4). The accumulation of $3 \mathrm{PG}$ and the apparent reduction in the pyruvate level (Figure 2) suggest that fluoride inhibits enolase, the enzyme that catalyzes the metabolic reaction between 3PG 


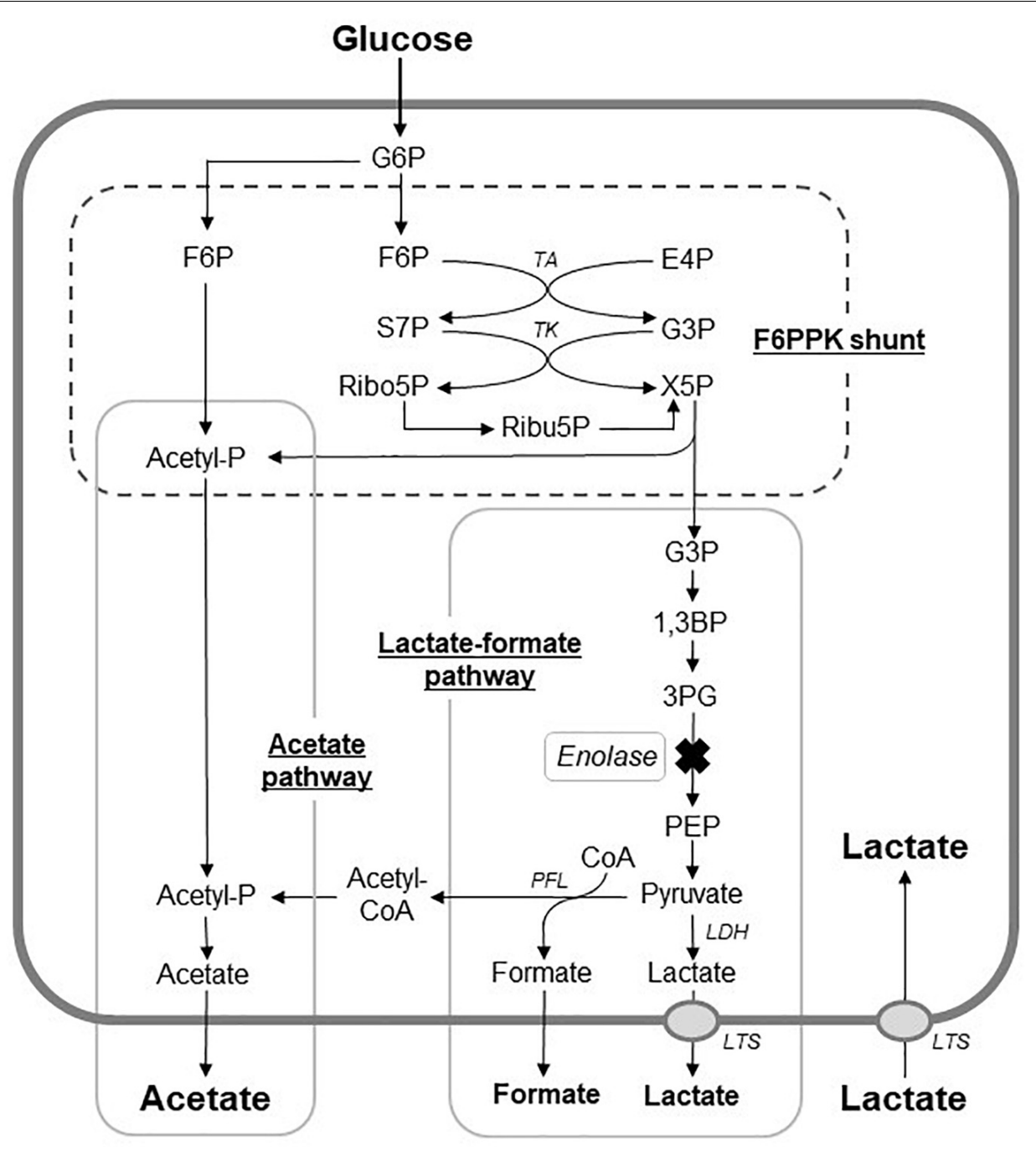

FIGURE 4 | Proposed metabolic pathways for glucose metabolism in S. wiggsiae. X mark, a step assumed to be inhibited by fluoride; G6P; glucose 6-phospahte; F6P, fructose 6-phosphate; E4P, erythrose 4-phosphate; S7P, sedoheptulose 7-phosphate; G3P, glyceraldehyde 3-phosphate; X5p, xylulose 5-phosphate; Ribo5P, ribose 5-phosphate; Ribu5P, ribulose 5-phosphate; 1,3BP, 1,3-bisphosphoglycerate; 3PG, 3-phosphoglycerate; PEP, phosphoenolpyruvate; Acetyl-P, CoA, coenzyme A; TA, transalodolase; TK, transketolase; LDH, lactate dehydrogenase; PFL, pyruvate formate-lyase; LTS, lactic acid transport system.

and pyruvate (Figure 4). Indeed, the present study confirmed that fluoride inhibited enolase activity in a concentrationdependent manner; however, $2 \mathrm{mM}$ fluoride inhibited the enolase activity of $S$. mutans and B. dentium by $90 \%$ (Manome et al., 2019), while it only inhibited the activity of S. wiggsiae by $<10 \%$, and the $\mathrm{IC}_{50}$ value was $4.6 \mathrm{mM}$, indicating that the enolase of $S$. wiggsiae is more fluoride-tolerant than those of other caries-associated bacteria (Table 2). The fact that S. wiggsiae possesses a fluoride-tolerant form of enolase might also make its carbohydrate metabolism activity more tolerant to fluoride. Although the reasons for the fluoride tolerance of S. weggsiae remain unclear, it is true that the sensitivity of enolase varies among oral bacteria (Guha-Chowdhury et al., 1997). The mechanism for the difference in fluoride sensitivity might be due to the conformational structure of enolase, since fluoride inhibition is closely related to the binding properties of magnesium, phosphate, and fluoride to the enolase protein (Qin et al., 2006).

In addition to fluoride, acids produced by bacteria can inhibit their carbohydrate metabolism (Carlsson and Hamilton, 1996). In the current study, lactic acid inhibited the acid production of $S$. mutans (Figure 3). This was considered to be due to the lactic acid transport system used by $S$. mutans for lactic acid excretion (Carlsson and Hamilton, 1996; Dashper and Reynolds, 1996) that caused lactic acid to flow into the bacterial cells and acidified the intracellular $\mathrm{pH}$, and hence, inhibited glucose metabolism. In acidic environments some acetic acid becomes undissociated, permeates through the cell membrane, enters bacterial cells and possibly inactivates bacterial metabolism by acidification, but the efficiency of acetic acid penetration is lower than that of the lactic acid transport system, and its inhibitory effects are considered to 
be negligible (Günther et al., 1991; Carlsson and Hamilton, 1996; Dashper and Reynolds, 1996). In the present study, the acid production of $S$. wiggsiae was not affected by lactic acid (Figure 3), presumably because $S$. wiggsiae does not possess a lactic acid transport system (Günther et al., 1991). In highly cariogenic environments, i.e., acidic environments in which a large amount of lactic acid is present, $S$. mutans might decrease its ability to metabolize carbohydrates and produce acid, whereas S. wiggsiae could continue to produce acid, suggesting that S. wiggsiae has high acidogenic and aciduric potential. This property might also make $S$. wiggsiae ecologically competitive in acidic environments, such as caries lesions.

\section{CONCLUSION}

The present study revealed that $S$. wiggsiae has high acid productivity and tolerance to fluoride and lactic/acetic acids. The acid productivity and acid tolerance of $S$. wiggsiae is thought to be equivalent to those of $S$. mutans. S. wiggsiae possesses a unique metabolic pathway, F6PPK shunt, which might contribute to its fluoride and acid tolerance by maintaining the metabolic flow to the fluoride-tolerant acetic acid-pathway. The tolerance of acid production to lactic acid may also provide $S$. wiggsiae with high ecological competitiveness in acidic environments such as caries lesions.

\section{REFERENCES}

Aizawa, S., Miyasawa-Hori, H., Nakajo, K., Washio, J., Mayanagi, H., Fukumoto, S., et al. (2009). Effects of alpha-amylase and its inhibitors on acid production from cooked starch by oral streptococci. Caries Res. 43, 17-24. doi: 10.1159/ 000189703

Becker, M. R., Paster, B. J., Leys, E. J., Moeschberger, M. L., Kenyon, S. G., Galvin, J. L., et al. (2002). Molecular analysis of bacterial species associated with childhood caries. J. Clin. Microbiol. 40, 1001-1009. doi: 10.1128/jcm.40.3.10011009.2002

Carlsson, J., and Hamilton, I. R. (1996). Differential toxic effects of lactate and acetate on the metabolism of Streptococcus mutans and Streptococcus sanguis. Oral Microbiol. Immunol. 11, 412-419. doi: 10.1111/j.1399-302x.1996. tb00204.x

Chandna, P., Srivastava, N., Sharma, A., Sharma, V., Gupta, N., and Adlakha, V. K. (2018). Isolation of Scardovia wiggsiae using real-time polymerase chain reaction from the saliva of children with early childhood caries. J. Indian Soc. Pedod. Prev. Dent. 36, 290-295. doi: 10.4103/JISPPD.JISP PD_225_17

Colombo, N. H., Kreling, P. F., Ribas, L. F. F., Pereira, J. A., Kressirer, C. A., Klein, M. I., et al. (2017). Quantitative assessment of salivary oral bacteria according to the severity of dental caries in childhood. Arch. Oral Biol. 83, 282-288. doi: $10.1016 / j$

Dashper, S. G., and Reynolds, E. C. (1996). Lactic acid excretion by Streptococcus mutans. Microbiology 142, 33-39. doi: 10.1099/13500872-142-1-33

Eriksson, L., Lif Holgerson, P., Esberg, A., and Johansson, I. (2018). Microbial complexes and caries in 17-year-olds with and without Streptococcus mutans. J. Dent. Res. 97, 275-282. doi: 10.1177/0022034517731758

Guha-Chowdhury, N., Clark, A. G., and Sissons, C. H. (1997). Inhibition of purified enolases from oral bacteria by fluoride. Oral Microbiol. Immunol. 12, 91-97. doi: 10.1111/j.1399-302x.1997.tb00623.x

Günther, G., Volker, M., and Gerhard, G. (1991). Lactic acid excretion via carriermediated facilitated diffusion in Lactobacillus helveticus. Microbiol. Biotechnol. $34,778-782$.

\section{DATA AVAILABILITY STATEMENT}

All datasets generated for this study are included in the article/supplementary material.

\section{AUTHOR CONTRIBUTIONS}

MK contributed to data acquisition and interpretation, drafted, and critically revised the manuscript. YA contributed to conception, design, data acquisition and interpretation, drafted and critically revised the manuscript. JW contributed to conception, design, data interpretation, drafted, and critically revised the manuscript for metabolome analysis CE-TOFMS. AT contributed to conception, design and manuscript review. CK contributed to conception and design. IM contributed to conception and design. NT contributed to conception, design, data interpretation, drafted, and critically revised the manuscript. All authors gave their final approval and agreed to be accountable for all aspects of the work.

\section{FUNDING}

This study was supported in part by Grants-in-Aid for Scientific Research (B) Nos. 26293439, 17H04420, and K18K099050, JSPS, Japan.

Hajishengallis, E., Parsaei, Y., Klein, M. I., and Koo, H. (2017). Advances in the microbial etiology and pathogenesis of early childhood caries. Mol. Oral Microbiol. 32, 24-34. doi: 10.1111/omi.12152

Hamilton, I. R. (1990). Biochemical effects of fluoride on oral bacteria. J. Dent. Res. $69,682-683$.

Hoppenbrouwers, P. M., and Driessens, F. C. (1988). The effect of lactic and acetic acid on the formation of artificial caries lesions. J. Dent. Res. 67, 1466-1467. doi: 10.1177/00220345880670120501

Iwami, Y., Abbe, K., Takahashi-Abbe, S., and Yamada, T. (1992). Acid production by streptococci growing at low $\mathrm{pH}$ in a chemostat under anaerobic conditions. Oral Microbiol. Immunol. 7, 304-308. doi: 10.1111/j.1399-302x.1992.tb00593.x

Jenkins, G. N. (1999). Review of fluoride research since 1959. Arch. Oral Biol. 44, 985-992. doi: 10.1016/s0003-9969(99)00110-7

Jian, W., and Dong, X. (2002). Transfer of Bifidobacterium inopinatum and Bifidobacterium denticolens to Scardovia inopinata gen. nov., comb. nov., and Parascardovia denticolens gen. nov., comb. nov., respectively. Int. J. Syst. Evol. Microbiol. 52, 809-812. doi: 10.1099/00207713-52-3-809

Kasebaum, N., Bernabe, J. E., Dahiya, M., Bhandari, B., Murray, C. J., and Marcenes, W. (2015). Global burden of untreated caries: a systematic review and metaregression. J. Dent. Res. 94, 650-658. doi: 10.1177/0022034515573272

Kawashima, J., Nakajo, K., Washio, J., Mayanagi, G., Shimauchi, H., and Takahashi, N. (2013). Fluoride-sensitivity of growth and acid production of oral Actinomyces: comparison with oral Streptococcus. Microbiol. Immunol. 57, 797-804. doi: 10.1111/1348-0421.12098

Manome, A., Abiko, Y., Kawashima, J., Washio, J., Fukumoto, S., and Takahashi, N. (2019). Acidogenic potential of oral Bifidobacterium and its high fluoride tolerance. Front. Microbiol. 16:1099. doi: 10.3389/fmicb.2019.01099

Mantzourani, M., Fenlon, M., and Beighton, D. (2009). Association between Bifidobacteriaceae and the clinical severity of root caries lesions. Oral Microbiol. Immunol. 24, 32-37. doi: 10.1111/j.1399-302X.2008.00470.x

Marquis, R. E. (1990). Diminished acid tolerance of plaque bacteria caused by fluoride. J. Dent. Res. 69, 682-683.

Norimatsu, Y., Kawashima, J., Takano-Yamamoto, T., and Takahashi, N. (2015). Nitrogenous compounds stimulate glucose-derived acid production by oral 
Streptococcus and Actinomyces. Microbiol. Immunol. 59, 501-506. doi: 10.1111/ 1348-0421.12283

Qin, J., Chai, G., Brewer, J. M., Lovelace, L. L., and Lebioda, L. (2006). Fluoride inhibition of enolase: crystal structure and thermodynamics. Biochemistry 45, 793-800. doi: 10.1021/bi051558s

Ruas-Madiedo, P., Hernández-Barranco, A., Margolles, A., and de los ReyesGavilán, C. G. (2005). A bile salt-resistant derivative of Bifidobacterium animalis has an altered fermentation pattern when grown on glucose and maltose. Appl. Environ. Microbiol. 71, 6564-6570. doi: 10.1128/aem.71.11.6564-6570.2005

Sánchez, B., Champomier-Vergès, M. C., Anglade, P., Baraige, F., de Los ReyesGavilán, C. G., Margolles, A., et al. (2005). Proteomic analysis of global changes in protein expression during bile salt exposure of Bifidobacterium longum NCIMB 8809. J. Bacteriol. 187, 5799-5808. doi: 10.1128/jb.187.16.5799-58 08.2005

Sutton, S. V., Bender, G. R., and Marquis, R. E. (1987). Fluoride inhibition of proton-translocating ATPases of oral bacteria. Infect. Immun. 55, 2597-2603. doi: 10.1128/iai.55.11.2597-2603.1987

Takahashi, N., Abbe, K., Takahashi-Abbe, S., and Yamada, T. (1987). Oxygen sensitivity of sugar metabolism and interconversion of pyruvate formate-lyase in intact cells of Streptococcus mutans and Streptococcus sanguis. Infect. Immun. 55, 652-656. doi: 10.1128/iai.55.3.652-65 6.1987

Takahashi, N., Horiuchi, M., and Yamada, T. (1997). Effects of acidification on growth and glycolysis of Streptococcus sanguis and Streptococcus mutans. Oral Microbiol. Immunol. 12, 72-76. doi: 10.1111/j.1399-302x.1997.tb00620.x

Takahashi, N., Washio, J., and Mayanagi, G. (2010). Metabolomics of supragingival plaque and oral bacteria. J. Dent. Res. 89, 1383-1388. doi: 10.1177/ 0022034510377792
Tanner, A. C., Kent, R. L. Jr., Holgerson, P. L., Hughes, C. V., Loo, C. Y., Kanasi, E., et al. (2011). Microbiota of severe early childhood caries before and after therapy. J. Dent. Res. 90, 1298-1305. doi: 10.1177/00220345114 21201

Tanner, A. C., Sonis, A. L., Lif Holgerson, P., Starr, J. R., Nunez, Y., Kressirer, C. A., et al. (2012). White-spot lesions and gingivitis microbiotas in orthodontic patients. J. Dent. Res. 91, 853-858. doi: 10.1177/0022034512455031

Tanner, A. C. R., Kressirer, C. A., Rothmiller, S., Johansson, I., and Chalmers, N. I. (2018). The caries microbiome: implications for reversing dysbiosis. Adv. Dent. Res. 29, 78-85. doi: 10.1177/0022034517736496

Tatevossian, A. (1990). Fluoride in dental plaque and its effects. J. Dent. Res. 69, 682-683.

Vogel, G. L., Zhang, Z., Chow, L. C., and Schumacher, G. E. (2002). Changes in lactate and other ions in plaque and saliva after a fluoride rinse and subsequent sucrose administration. Caries Res. 36, 44-52. doi: 10.1159/00005 7590

Conflict of Interest: The authors declare that the research was conducted in the absence of any commercial or financial relationships that could be construed as a potential conflict of interest.

Copyright (c) 2020 Kameda, Abiko, Washio, Tanner, Kressirer, Mizoguchi and Takahashi. This is an open-access article distributed under the terms of the Creative Commons Attribution License (CC BY). The use, distribution or reproduction in other forums is permitted, provided the original author(s) and the copyright owner(s) are credited and that the original publication in this journal is cited, in accordance with accepted academic practice. No use, distribution or reproduction is permitted which does not comply with these terms. 